\title{
A prospective clinical pilot study on the effects of a hydrogen peroxide mouthrinse on the intraoral viral load of SARS-CoV-2
}

\author{
Maximilian J. Gottsauner ${ }^{1}$ - Ioannis Michaelides ${ }^{2}$ - Barbara Schmidt ${ }^{3} \cdot$ Konstantin J. Scholz $^{4} \cdot$ Wolfgang Buchalla ${ }^{4}$. \\ Matthias Widbiller ${ }^{4} \cdot$ Florian Hitzenbichler ${ }^{5} \cdot$ Tobias Ettl $^{1} \cdot$ Torsten E. Reichert $^{1}$. Christopher Bohr ${ }^{2}$. \\ Veronika Vielsmeier ${ }^{2} \cdot$ Fabian Cieplik $^{4}$ (1)
}

Received: 29 July 2020 / Accepted: 24 August 2020 / Published online: 2 September 2020

(C) The Author(s) 2020

\begin{abstract}
Objectives SARS-CoV-2 is mainly transmitted by inhalation of droplets and aerosols. This puts healthcare professionals from specialties with close patient contact at high risk of nosocomial infections with SARS-CoV-2. In this context, preprocedural mouthrinses with hydrogen peroxide have been recommended before conducting intraoral procedures. Therefore, the aim of this study was to investigate the effects of a $1 \%$ hydrogen peroxide mouthrinse on reducing the intraoral SARS-CoV-2 load.

Methods Twelve out of 98 initially screened hospitalized SARS-CoV-2-positive patients were included in this study. Intraoral viral load was determined by RT-PCR at baseline, whereupon patients had to gargle mouth and throat with $20 \mathrm{~mL}$ of $1 \%$ hydrogen peroxide for $30 \mathrm{~s}$. After $30 \mathrm{~min}$, a second examination of intraoral viral load was performed by RT-PCR. Furthermore, virus culture was performed for specimens exhibiting viral load of at least $10^{3} \mathrm{RNA}$ copies $/ \mathrm{mL}$ at baseline.

Results Ten out of the 12 initially included SARS-CoV-2-positive patients completed the study. The hydrogen peroxide mouthrinse led to no significant reduction of intraoral viral load. Replicating virus could only be determined from one baseline specimen.

Conclusion A $1 \%$ hydrogen peroxide mouthrinse does not reduce the intraoral viral load in SARS-CoV-2-positive subjects. However, virus culture did not yield any indication on the effects of the mouthrinse on the infectivity of the detected RNA copies. Clinical relevance The recommendation of a preprocedural mouthrinse with hydrogen peroxide before intraoral procedures is questionable and thus should not be supported any longer, but strict infection prevention regimens are of paramount importance. Trial registration German Clinical Trials Register (ref. DRKS00022484)
\end{abstract}

Keywords SARS-CoV-2 $\cdot$ COVID-19 $\cdot$ Hydrogen peroxide $\cdot$ Mouthrinse $\cdot$ Gargle $\cdot$ Intraoral $\cdot$ Viral load

Maximilian J. Gottsauner and Ioannis Michaelides contributed equally and share first authorship.

$\overline{\text { Veronika Vielsmeier and Fabian Cieplik contributed equally and share }}$ senior authorship.

Fabian Cieplik

fabian.cieplik@ukr.de

1 Department of Oral and Maxillofacial Surgery, University Hospital Regensburg, Regensburg, Germany

2 Department of Otorhinolaryngology, University Hospital Regensburg, Regensburg, Germany

3 Institute of Clinical Microbiology and Hygiene, University Hospital Regensburg, Regensburg, Germany

4 Department of Conservative Dentistry and Periodontology, University Hospital Regensburg, Franz-Josef-Strauß-Allee 11, 93053 Regensburg, Germany

5 Department of Infection Prevention and Infectious Diseases, University Hospital Regensburg, Regensburg, Germany

\section{Introduction}

The coronavirus disease 2019 (COVID-2019), which is caused by a novel coronavirus SARS-CoV-2 (severe acute respiratory syndrome coronavirus 2), amounts to more than 19.9 million confirmed cases and more than 730,000 attributed deaths, as per August 11, 2020, and thus represents one of the greatest challenges for the whole healthcare sector in the twenty-first century [1].

The main routes of SARS-CoV-2 transmission are by direct contact or by airborne transmission due to inhalation of aerosols and respiratory droplets [2]. This puts healthcare professionals (HCPs) at high risk of nosocomial infection with SARS-CoV-2 [3], as it was already shown by a disproportionally high infection rate for HCPs in an early report from Wuhan, China [4]. Patients with SARS-CoV-2 infection exhibit a very high 
viral load in the oropharynx, the oral cavity, and the nose, irrespective of the presence of clinical symptoms $[2,5]$. Therefore, particularly HCPs from specialties with close contact to this region such as dentists, maxillofacial surgeons, and otorhinolaryngologists are at tremendous risk of being infected and becoming potential carriers of the virus [6-13]. Accordingly, the first COVID-19related fatality of a medical doctor documented globally was that of an otorhinolaryngologist in Wuhan on January 25, 2020 [14]. Furthermore, clinical procedures in these specialties and particularly in clinical dentistry often involve generation of aerosols [15], which further increases the risks of nosocomial infection with SARSCoV-2 among HCPs [11].

Therefore, special infection control regimens have been introduced in dental practices all over the world, including patient triage, personal protective equipment (such as particulate respirators based on n-95 or FFP2 standards), use of rubber dam isolation, and general limitation of aerosolgenerating procedures $[7-9,11,16,17]$. Following a first recommendation by Peng et al. [12], some author groups also proposed to let patients perform preprocedural mouthrinses with oxidizing agents such as $1 \%$ hydrogen peroxide or $0.2 \%$ povidone iodine in order to reduce the intraoral viral load before conducting any intraoral procedures $[7-9,17,18]$. Accordingly, the American Dental Association suggested on their website on March 12, 2020 , to have patients gargle with a $1 \%$ hydrogen peroxide solution before each appointment [19]. Likewise, this suggestion was also disseminated among German dentists by the Institut der Deutschen Zahnärzte in their brochure about recommended standard dental procedures during the COVID-19 pandemic from April 24, 2020 [20].

The recommendation of a preprocedural mouthrinse with hydrogen peroxide was mainly based on the general vulnerability of SARS-CoV-2 toward oxidation [12], and on the finding that products containing oxidizing agents such as hydrogen peroxide and povidone iodine were able to inactivate coronaviruses on inanimate surfaces within a 1-min exposure period [21, 22]. However, until now, there are no clinical data supporting the efficacy of suchlike preprocedural mouthrinses in terms of reducing the intraoral viral load in SARS-CoV-2-infected patients [23-26]. Due to the high viral load in the oropharynx and the oral cavity, there may be some recontamination soon after performing the mouthrinse [27]. Furthermore, caution should be taken before generally recommending antimicrobial mouthrinses due to the inherent risks of inducing detrimental shifts in the oral ecosystem [28].

Therefore, the aim of this clinical pilot study was to investigate the effects of a mouthrinse with $1 \%$ hydrogen peroxide on the intraoral viral load in SARS-CoV-2positive patients.

\section{Material and methods}

\section{Study design}

The present study is a prospective clinical pilot study investigating the effects of a mouthrinse with $1 \%$ hydrogen peroxide on the intraoral viral load of SARS-CoV-2-positive patients hospitalized at the isolation ward of the University Hospital Regensburg during an investigation period of 2 months from April until May 2020.

Only patients with a positive test for SARS-CoV-2 within the last $72 \mathrm{~h}$ were included in this study. Exclusion criteria were indication for intubation or mechanical ventilation and severe stomatitis.

Patients were screened for eligibility by one medical doctor (IM) and provided with detailed description of the study outline which involved the following procedure: patients were asked to gargle their mouth and throat with $20 \mathrm{~mL} 0.9 \%$ $\mathrm{NaCl}$ for $30 \mathrm{~s}$ for acquiring a baseline oropharyngeal specimen for the SARS-CoV-2 real-time PCR (RT-PCR) test. Immediately afterwards, patients had to perform a mouthrinse with $20 \mathrm{~mL} 1 \%$ hydrogen peroxide by gargling their mouth and throat for $30 \mathrm{~s}$. Thirty minutes after this mouthrinse, another oropharyngeal specimen for the SARS-CoV-2 RT-PCR test was acquired by letting the patients gargle their mouth and throat with $20 \mathrm{~mL} 0.9 \% \mathrm{NaCl}$ for $30 \mathrm{~s}$. The respective quantities of copies/mL of SARS-CoV-2 RNA were analyzed by RT-PCR.

Written informed consent was obtained from all individual participants included in the study. The study design was approved by the ethics committee of the University of Regensburg (ref. 20-1787-101) in accordance with the 1964 Helsinki declaration and its later amendments or comparable ethical standards. The study has been registered at the German Clinical Trials Register (ref. DRKS00022484).

\section{RT-PCR-based analysis of viral load}

Nucleic acids were extracted from $200 \mu \mathrm{L}$ of oropharyngeal specimens using EZ1 Virus Mini Kit v2.0 in combination with the EZ1 Advanced XL system (Qiagen, Hilden, Germany), as recommended by the manufacturer. Viral RNA was amplified and detected in duplicate using the SARS-CoV-2 E gene RT-PCR [29] on the StepOnePlus RT-PCR System (ThermoFisherScientific, Schwerte, Germany). Bacteriophage MS2 was used as internal control to check for extraction and amplification efficacy [30].

\section{Virus culture}

SARS-CoV-2 was isolated from the oropharyngeal specimens that exhibited more than $10^{3}$ copies/mL of SARS-CoV-2 RNA at baseline by using kidney epithelial cells from African green 
monkey (Vero-CCL19 cells, ATCC). Cells were cultivated in Dulbecco's Modified Eagle's Medium supplemented with $10 \%$ heat-inactivated fetal calf serum (Sigma-Aldrich, Munich, Germany), $90 \mathrm{U} / \mathrm{mL}$ streptomycin, $0.3 \mathrm{mg} / \mathrm{mL}$ glutamine, $200 \mathrm{U} / \mathrm{mL}$ penicillin, and $2.5 \mu \mathrm{g} / \mathrm{mL}$ amphotericin B (PAN Biotech, Aidenbach, Germany). After inoculation of oropharyngeal specimens for $24 \mathrm{~h}$, cells were washed twice before viral loads in the supernatants were determined 7 days postinfection by RT-PCR as described above.

\section{Data analysis}

Data are reported as median values (with 1st and 3rd quartiles) and were statistically analyzed non-parametrically using the Wilcoxon signed-rank test for related samples on a significance level of $\alpha=0.05$. All statistical analyses were performed using IBM SPSS Statistics, version 25 (IBM Corp., Armonk, NY, USA).

\section{Results}

\section{Patient population}

Twelve SARS-CoV-2-positive patients were included in this study. These 12 patients ( 6 female and 6 male) had a median age of 55 years (range: $22-81$ years). One patient was hospitalized in an intensive care unit (without need of intubation), and 11 were hospitalized in an isolation ward. Eleven out of the 12 patients showed comorbidities (e.g., diseases of the liver, cardiovascular system or kidney, hematological diseases, and obesity). Only one of the patients presented no symptoms of the infection with SARS-CoV-2. The time period between diagnosis of SARS-CoV-2 infection and inclusion in the study ranged from 1 to 5 days (median 3 days). Table 1 shows a detailed overview of the patient population included in this study. Figure 1 shows the flow of patients through the stages of this study.

\section{RT-PCR-based analysis of viral load prior and after $1 \%$ hydrogen peroxide mouthrinse}

In two out of the 12 initially included patients, no SARS-CoV2 RNA could be detected in the baseline specimens prior to performing the $1 \%$ hydrogen peroxide mouthrinse. Therefore, these two patients were excluded from the study.

Table 2 shows the viral load of the remaining 10 individual patients at baseline and $30 \mathrm{~min}$ after the $1 \%$ hydrogen peroxide mouthrinse. The baseline specimens exhibited a median (1st; $3 \mathrm{rd}$ quartile) viral load of $1.8 \times 10^{3}\left(3.1 \times 10^{2} ; 4.7 \times 10^{4}\right)$ copies $/ \mathrm{mL}$ of SARS-CoV-2 RNA. The second analysis $30 \mathrm{~min}$ after the $1 \%$ hydrogen peroxide mouthrinse showed a median (1st; 3rd quartile) viral load of $1.5 \times 10^{3}\left(8.3 \times 10^{2} ; 3.4 \times 10^{4}\right) \mathrm{copies} / \mathrm{mL}$ of SARS-CoV-2 RNA (Fig. 2). There were no significant

Table 1 Patient characteristics

\begin{tabular}{|c|c|c|c|c|c|}
\hline Patient no. & Sex & Age & Admission symptoms & Underlying diseases & $\begin{array}{l}\text { Period between diagnosis } \\
\text { and study inclusion (days) }\end{array}$ \\
\hline $1 *$ & $\mathrm{w}$ & 60 & Reduced general condition, cough, fever & Obesity, arterial hypertension & 5 \\
\hline 2 & $\mathrm{w}$ & 55 & Fever, genitourinary infection & $\begin{array}{l}\mathrm{H} / \mathrm{O} \text { liver transplant with } \\
\text { immunosuppression }\end{array}$ & 3 \\
\hline 3 & $\mathrm{~m}$ & 56 & Loss of appetite & Cirrhosis of the liver & 2 \\
\hline 4 & $\mathrm{~m}$ & 43 & Reduced general condition, dyspnea & $\begin{array}{l}\text { Granulomatosis with polyangiitis, } \\
\text { H/O renal cell carcinoma }\end{array}$ & 1 \\
\hline 5 & $\mathrm{~m}$ & 77 & Cough, dyspnea & $\begin{array}{l}\text { Chronic lymphocytic leukemia, multiple } \\
\text { myeloma, arterial hypertension }\end{array}$ & 1 \\
\hline 6 & $\mathrm{w}$ & 57 & Hydropic decompensation & $\begin{array}{l}\text { Cirrhosis of the liver, coronary heart disease, } \\
\text { depression, restless legs syndrome }\end{array}$ & 3 \\
\hline $7 *$ & $\mathrm{w}$ & 81 & Tiredness & Anemia, $\mathrm{H} / \mathrm{O}$ aortic valve replacement & 4 \\
\hline 8 & $\mathrm{w}$ & 47 & $\begin{array}{l}\text { Reduced general condition, cephalalgia, } \\
\text { sore throat }\end{array}$ & Epilepsy & 1 \\
\hline 9 & $\mathrm{~m}$ & 22 & Reduced general condition, dyspnea & No underlying diseases & 5 \\
\hline 10 & $\mathrm{~m}$ & 67 & $\begin{array}{l}\text { No symptoms. Positive in } \\
\text { preoperative screening }\end{array}$ & Symptomatic coronary heart disease & 4 \\
\hline 11 & $\mathrm{w}$ & 39 & Acute on chronic renal failure, exsiccosis & $\begin{array}{l}\text { Chronic renal failure caused by familial } \\
\text { primary hypomagnesemia with } \\
\text { hypercalciuria and nephrocalcinosis }\end{array}$ & 3 \\
\hline 12 & $\mathrm{~m}$ & 61 & Reduced general condition, cough, fever & $\begin{array}{l}\text { Chronic renal failure, arterial hypertension, } \\
\text { coronary heart disease, obstructive sleep } \\
\text { apnea, obesity }\end{array}$ & 5 \\
\hline
\end{tabular}

*These two patients were excluded from this study since no SARS-CoV-2 RNA could be detected in the baseline specimens prior to performing the $1 \%$ hydrogen peroxide mouthrinse 


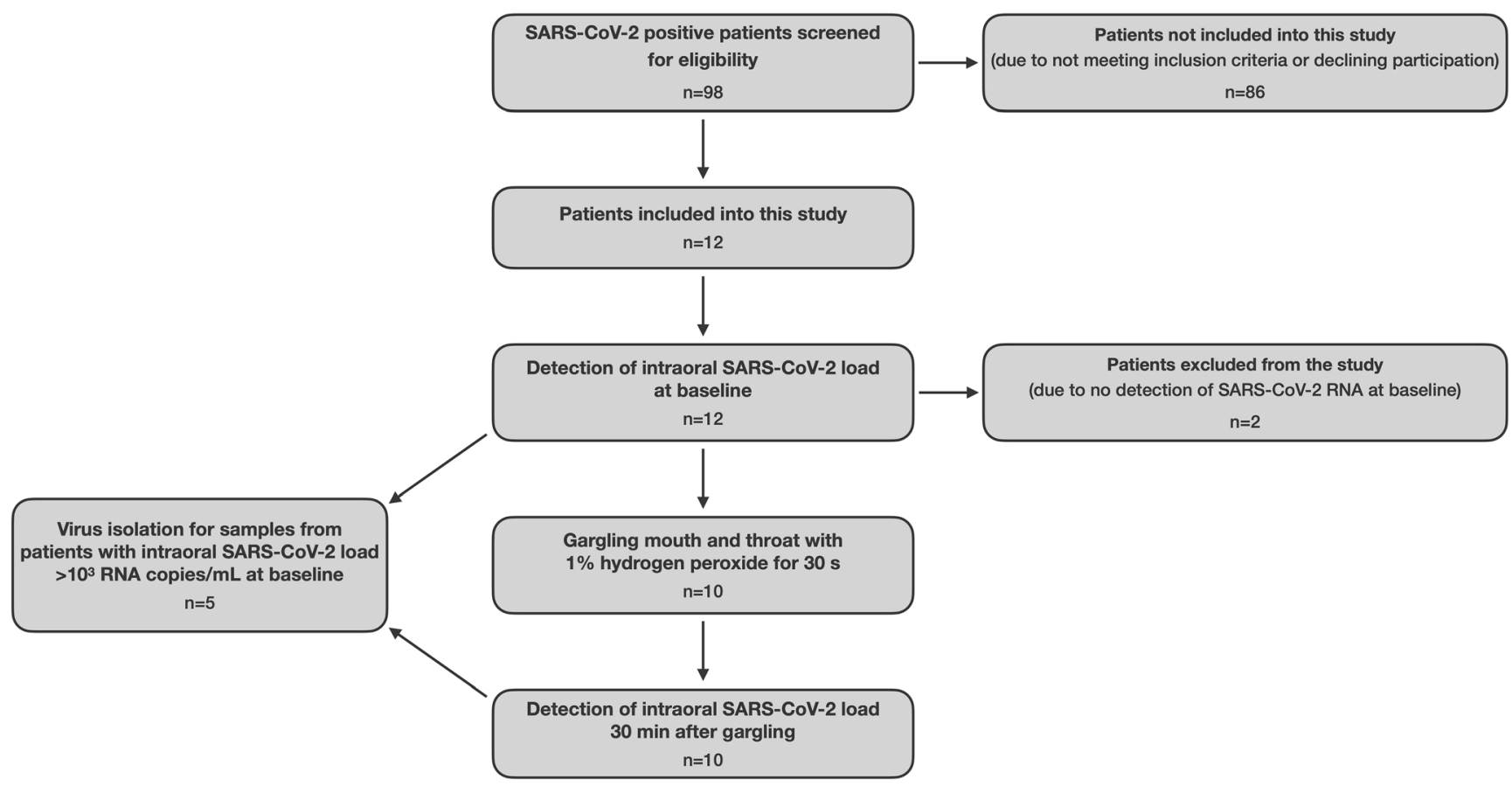

Fig. 1 Flow of patients through the stages of this study

differences between baseline viral load and viral load $30 \mathrm{~min}$ after the $1 \%$ hydrogen peroxide mouthrinse $(p=0.96)$.
copies/mL of SARS-CoV-2 RNA at baseline. Replicating virus could only be detected in one baseline specimen (Table 2).

\section{Virus culture}

Virus culture was performed by infecting Vero cells and assessing the viral load in the supernatants 7 days postinfection for the specimens that exhibited more than $10^{3}$

\section{Discussion}

The COVID-19 pandemic caused an exceptional situation where HCPs needed to develop infection control regimens
Table 2 Intraoral viral load and virus culture

\begin{tabular}{|c|c|c|c|c|}
\hline \multirow[t]{2}{*}{ Patient no. } & \multicolumn{2}{|l|}{ Baseline } & \multicolumn{2}{|c|}{$\begin{array}{l}30 \text { min after gargling with } 1 \% \text { hydrogen } \\
\text { peroxide mouthrinse }\end{array}$} \\
\hline & $\begin{array}{l}\text { Copies/mL of } \\
\text { SARS-CoV-2 RNA }\end{array}$ & Virus culture & $\begin{array}{l}\text { Copies/mL of } \\
\text { SARS-CoV-2 RNA }\end{array}$ & Virus culture \\
\hline $1 *$ & 0 & l & l & l \\
\hline 2 & $5.7 \times 10^{2}$ & l & $6.3 \times 10^{2}$ & l \\
\hline 3 & $7.9 \times 10^{2}$ & / & $2.9 \times 10^{2}$ & l \\
\hline 4 & $2.9 \times 10^{2}$ & / & $1.2 \times 10^{3}$ & l \\
\hline 5 & $9.6 \times 10^{4}$ & Negative & $1.0 \times 10^{5}$ & Negative \\
\hline 6 & $2.8 \times 10^{3}$ & Negative & $1.1 \times 10^{3}$ & Negative \\
\hline $7 *$ & 0 & / & l & / \\
\hline 8 & $4.8 \times 10^{6}$ & Negative & $9.3 \times 10^{4}$ & Negative \\
\hline 9 & $3.2 \times 10^{2}$ & / & $8.9 \times 10^{2}$ & / \\
\hline 10 & $3.7 \times 10^{3}$ & Negative & $1.4 \times 10^{4}$ & Negative \\
\hline 11 & $2.9 \times 10^{2}$ & / & $1.7 \times 10^{3}$ & / \\
\hline 12 & $3.0 \times 10^{4}$ & Positive & $3.7 \times 10^{3}$ & Negative \\
\hline
\end{tabular}

*These two patients were excluded from this study since no SARS-CoV-2 RNA could be detected in the baseline specimens prior to performing the $1 \%$ hydrogen peroxide mouthrinse

Solidus (/), not performed 
Fig. 2 Copies/mL of SARSCoV-2 RNA at baseline and $30 \mathrm{~min}$ after $1 \%$ hydrogen peroxide mouthrinse. All results are depicted as boxplots, which display medians, 1st and 3rd quartiles (box), minima and maxima (whiskers)

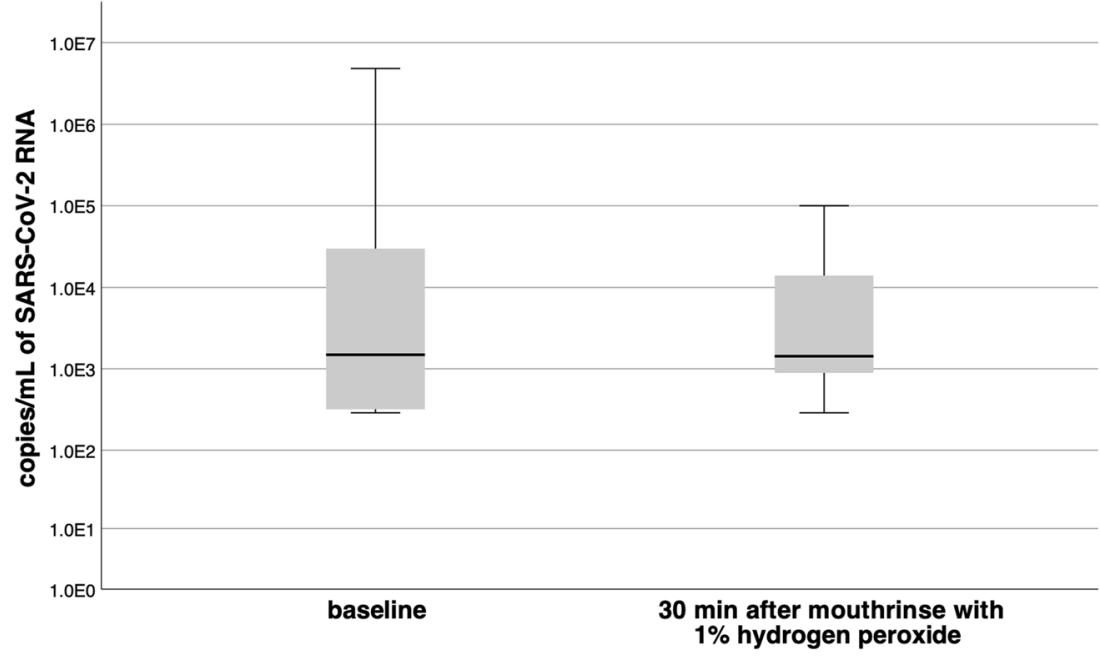

This study revealed that a $1 \%$ hydrogen peroxide mouthrinse had no effect on reducing the intraoral viral load in SARS-CoV2-positive subjects. Therefore, any mechanical effects due to the mouthrinse itself irrespective of its ingredients can be excluded. As RT-PCR-based analysis is only able to detect RNA copies but cannot give any indication on the infectivity of the detected virus fragments, we further tried to culture SARS-CoV-2 virus from the patients whose baseline specimens exhibited a viral load of at least $10^{3}$ RNA copies per $\mathrm{mL}$. These specimens were used for infecting Vero cells, and the viral load was determined in the supernatants 7 days post-infection. Here, active virus replication could only be detected from one baseline specimen, thus not allowing conclusions on the effects of hydrogen peroxide on SARS-CoV-2 infectivity. Wölfel et al. showed that virus culture depends on viral load with specimens containing less than $10^{6}$ RNA copies per mL hardly yielding successful culture [36]. Therefore, the rather low median viral load of $1.8 \times 10^{3}$ RNA copies $/ \mathrm{mL}$ in the baseline specimens may be accounted for the absence of active virus replication after infection of cell cultures in most specimens of the present study. Likewise, To et al. found active virus in only 3 out of 12 saliva specimens from SARSCoV-2-positive patients despite that the median viral load in these specimens was markedly higher $\left(3.3 \times 10^{6}\right.$ RNA copies $/ \mathrm{mL}$ ) than in the present study [35]. The rather low median numbers of RNA copies per $\mathrm{mL}$ found in this study may mainly be due to the exclusion of patients with indication for intubation or mechanical ventilation, because it is well-known that the oropharyngeal and nasopharyngeal SARS-CoV-2 viral load strongly correlates with COVID-19 severity [24, 37]. On the other hand, inclusion of hospitalized patients with rather mild symptoms of COVID-19 like in the present study may rather represent the patient population of interest for the scope of this study. Asymptomatic patients or patients with mild symptoms, who are not aware that they are SARS-CoV-2 positive, may tend to visit dental, maxillofacial, or otorhinolaryngological practices more often than those with severe symptoms.

HCPs $[34,35]$. 
Despite the small number of patients included in this pilot study, the results reported here clearly show that gargling mouth and throat with a $1 \%$ hydrogen peroxide mouthrinse for $30 \mathrm{~s}$ does not decrease the intraoral viral load in SARS-CoV-2positive subjects. In a very recent in vitro study, Bidra et al. investigated the virucidal effects of $1.5 \%$ and $3.0 \%$ hydrogen peroxide and $1.0 \%, 2.5 \%$ and $3.0 \%$ povidone iodine toward SARS-CoV-2 [38]. They incubated the test compounds with virus solution for 15 or $30 \mathrm{~s}$, respectively, and then conducted a standard end-point dilution assay by plating the serially diluted surviving virus on Vero 76 cells. Presence or absence of cytopathic effects was assessed after incubation for 5 days. They found that $1.5 \%$ and $3.0 \%$ hydrogen peroxide had only minimal virucidal activity toward SARS-CoV-2, whereas povidone iodine led to the complete inactivation of SARS-CoV-2 at the lowest concentration of $0.5 \%$ and the lowest contact time of $15 \mathrm{~s}$ [38]. Based on this in vitro data, further studies should investigate the effects of povidone iodine mouthrinses on the intraoral viral load in SARS-CoV-2-positive subjects [24].

In view of the results of this clinical pilot study and the in vitro results reported by Bidra et al. [38], the recommendation of a preprocedural mouthrinse with hydrogen peroxide before any intraoral procedures is questionable and thus should not be supported any longer. In this context, the impact of a "false sense of security" in HCPs due to the hydrogen peroxide mouthrinse and consequent unfocused treatment of potentially infectious patients should be considered. Therefore, strict infection prevention regimens concerning infection of HCPs are of paramount importance until further studies are available.

\section{Conclusion}

This pilot study shows that gargling mouth and throat with $1 \%$ hydrogen peroxide does not decrease the intraoral viral load in SARS-CoV-2-positive subjects. Further studies should investigate preprocedural mouthrinses containing other agents like povidone iodine for reducing the intraoral SARS-CoV-2 load. In the meantime, risk stratification by patient triage, obtaining a detailed anamnesis, providing personal protective equipment, and preventing the formation of droplets and aerosols during the treatment of patients appear to represent the most reliable infection control regimens for HCPs until further studies are available.

Funding Barbara Schmidt acknowledges financial support through the pandemic responsiveness fund of the Bavarian State Ministry of Sciences and Art. Open Access funding provided by Projekt DEAL.

\section{Compliance with ethical standards}

Conflict of interest All authors declare that they have no conflicts of interest.
Ethical approval All procedures performed in this study were in accordance with the ethical standards of the institutional research committee and with the 1964 Helsinki declaration and its later amendments. The study design was approved by the ethics committee of the University of Regensburg (ref. 20-1787-101). The study has been registered at the German Clinical Trials Register (ref. DRKS00022484).

Informed consent Written informed consent was obtained from all individual patients included in this study.

Open Access This article is licensed under a Creative Commons Attribution 4.0 International License, which permits use, sharing, adaptation, distribution and reproduction in any medium or format, as long as you give appropriate credit to the original author(s) and the source, provide a link to the Creative Commons licence, and indicate if changes were made. The images or other third party material in this article are included in the article's Creative Commons licence, unless indicated otherwise in a credit line to the material. If material is not included in the article's Creative Commons licence and your intended use is not permitted by statutory regulation or exceeds the permitted use, you will need to obtain permission directly from the copyright holder. To view a copy of this licence, visit http://creativecommons.org/licenses/by/4.0/.

\section{References}

1. World Health Organization (WHO) Coronavirus disease (COVID19) situation report 204, 11 August 2020

2. van Doremalen N, Bushmaker T, Morris DH, Holbrook MG, Gamble A, Williamson BN, Tamin A, Harcourt JL, Thornburg NJ, Gerber SI, Lloyd-Smith JO, de Wit E, Munster VJ (2020) Aerosol and surface stability of SARS-CoV-2 as compared with SARS-CoV-1. N Engl J Med 382:1564-1567. https://doi.org/10. 1056/NEJMc2004973

3. Wilson NM, Norton A, Young FP, Collins DW (2020) Airborne transmission of severe acute respiratory syndrome coronavirus- 2 to healthcare workers: a narrative review. Anaesthesia 75:1086-1095. https://doi.org/10.1111/anae.15093

4. Wang D, Hu B, Hu C, Zhu F, Liu X, Zhang J, Wang B, Xiang H, Cheng Z, Xiong Y, Zhao Y, Li Y, Wang X, Peng Z (2020) Clinical characteristics of 138 hospitalized patients with 2019 novel coronavirus-infected pneumonia in Wuhan, China. JAMA 323: 1061-1069. https://doi.org/10.1001/jama.2020.1585

5. Zou L, Ruan F, Huang M, Liang L, Huang H, Hong Z, Yu J, Kang M, Song Y, Xia J, Guo Q, Song T, He J, Yen HL, Peiris M, Wu J (2020) SARS-CoV-2 viral load in upper respiratory specimens of infected patients. N Engl J Med 382:1177-1179. https://doi.org/10. 1056/NEJMc2001737

6. Krajewska J, Krajewski W, Zub K, Zatoński T (2020) COVID-19 in otolaryngologist practice: a review of current knowledge. Eur Arch Otorhinolaryngol 277:1885-1897. https://doi.org/10.1007/ s00405-020-05968-y

7. Ather A, Patel B, Ruparel NB, Diogenes A, Hargreaves KM (2020) Coronavirus disease 19 (COVID-19): implications for clinical dental care. J Endod 46:584-595. https://doi.org/10.1016/j.joen.2020. 03.008

8. Izzetti R, Nisi M, Gabriele M, Graziani F (2020) COVID-19 transmission in dental practice: brief review of preventive measures in Italy. J Dent Res 99:1030-1038. https://doi.org/10.1177/ 0022034520920580

9. Zimmermann M, Nkenke E (2020) Approaches to the management of patients in oral and maxillofacial surgery during COVID-19 
pandemic. J Craniomaxillofac Surg 48:521-526. https://doi.org/10. 1016/j.jcms.2020.03.011

10. Spagnuolo G, De Vito D, Rengo S, Tatullo M (2020) COVID-19 outbreak: an overview on dentistry. Int J Environ Res Public Health 17:2094. https://doi.org/10.3390/ijerph17062094

11. Meng L, Hua F, Bian Z (2020) Coronavirus disease 2019 (COVID19): emerging and future challenges for dental and oral medicine. J Dent Res 99:481-487. https://doi.org/10.1177/0022034520914246

12. Peng X, Xu X, Li Y, Cheng L, Zhou X, Ren B (2020) Transmission routes of 2019-nCoV and controls in dental practice. Int J Oral Sci 12:9. https://doi.org/10.1038/s41368-020-0075-9

13. Cheng X, Liu J, Li N, Nisenbaum E, Sun Q, Chen B, Casiano R, Weed D, Telischi F, Denneny JC III, Liu X, Shu Y (2020) Otolaryngology providers must be alert for patients with mild and asymptomatic COVID-19. Otolaryngol Head Neck Surg 162:809810. https://doi.org/10.1177/0194599820920649

14. Chan JYK, Wong EWY, Lam W (2020) Practical aspects of otolaryngologic clinical services during the 2019 novel coronavirus epidemic: an experience in Hong Kong. JAMA Otolaryngol Head Neck Surg 146:519-520. https://doi.org/10.1001/jamaoto.2020. 0488

15. Zemouri C, de Soet H, Crielaard W, Laheij A (2017) A scoping review on bio-aerosols in healthcare and the dental environment. PLoS One 12:e178007. https://doi.org/10.1371/journal.pone. 0178007

16. Cirillo N (2020) COVID-19 outbreak: succinct advice for dentists and oral healthcare professionals. Clin Oral Investig 24:2529-2535. https://doi.org/10.1007/s00784-020-03323-3

17. Diegritz C, Manhart J, Bücher K, Grabein B, Schuierer G, Kühnisch J, Kunzelmann KH, Hickel R, Fotiadou C (2020) A detailed report on the measures taken in the Department of Conservative Dentistry and Periodontology in Munich at the beginning of the COVID-19 outbreak. Clin Oral Investig 24:29312941. https://doi.org/10.1007/s00784-020-03440-z

18. Jamal M, Shah M, Almarzooqi SH, Aber H, Khawaja S, el Abed R, Alkhatib Z, Samaranayake LP (2020) Overview of transnational recommendations for COVID-19 transmission control in dental care settings. Oral Dis. https://doi.org/10.1111/odi.13431

19. American Dental Association (ADA) (2020) ADA adds frequently asked questions from dentists to coronavirus resources. ADA American Dental Association. Available at: https://www.ada.org/ en/publications/ada-news/2020-archive/march/ada-addsfrequently-asked-questions-from-dentists-to-coronavirus-resources

20. Institut der Deutschen Zahnärzte (IDZ) (2020) System von Standardvorgehensweisen für Zahnarztpraxen während der Coronavirus-Pandemie. Available at: https://www.idz.institute/ fileadmin/Content/Publikationen-PDF/Weitere Dokumente/IDZ SARS-CoV-2_Standardvorgehensweise_ZAP_2020-04-24.pdf

21. Kampf G, Todt D, Pfaender S, Steinmann E (2020) Persistence of coronaviruses on inanimate surfaces and their inactivation with biocidal agents. J Hosp Infect 104:246-251. https://doi.org/10.1016/j. jhin.2020.01.022

22. Kampf G, Todt D, Pfaender S, Steinmann E (2020) Corrigendum to "Persistence of coronaviruses on inanimate surfaces and their inactivation with biocidal agents" [J Hosp Infect 104 (2020) 246-251]. J Hosp Infect 105:587. https://doi.org/10.1016/j.jhin.2020.06.001

23. Caruso AA, Del Prete A, Lazzarino AI (2020) Hydrogen peroxide and viral infections: a literature review with research hypothesis definition in relation to the current covid-19 pandemic. Med Hypotheses 144:109910. https://doi.org/10.1016/j.mehy.2020. 109910

24. Herrera D, Serrano J, Roldán S, Sanz M (2020) Is the oral cavity relevant in SARS-CoV-2 pandemic? Clin Oral Investig 24:29252930. https://doi.org/10.1007/s00784-020-03413-2
25. Ortega KL, Rodrigues de Camargo A, Bertoldi Franco J, Mano Azul A, Pérez Sayáns M, Braz Silva PH (2020) SARS-CoV-2 and dentistry. Clin Oral Investig 24:2541-2542. https://doi.org/10. 1007/s00784-020-03381-7

26. Ortega KL, Rech B d O, Ferreira Costa AL et al (2020) Is $0.5 \%$ hydrogen peroxide effective against SARS-CoV-2? Oral Dis. https://doi.org/10.1111/odi.13503

27. Volgenant CMC, Persoon IF, de Ruijter RAG, de Soet JJH (2020) Infection control in dental health care during and after the SARSCoV-2 outbreak. Oral Dis. https://doi.org/10.1111/odi.13408

28. Bescos R, Casas-Agustench P, Belfield L, Brookes Z, Gabaldón T (2020) Coronavirus disease 2019 (COVID-19): emerging and future challenges for dental and oral medicine. J Dent Res 99:1113. https://doi.org/10.1177/0022034520932149

29. Corman VM, Landt O, Kaiser M, Molenkamp R, Meijer A, Chu DKW, Bleicker T, Brünink S, Schneider J, Schmidt ML, Mulders DGJC, Haagmans BL, van der Veer B, van den Brink S, Wijsman L, Goderski G, Romette JL, Ellis J, Zambon M, Peiris M, Goossens H, Reusken C, Koopmans MPG, Drosten C (2020) Detection of 2019 novel coronavirus (2019-nCoV) by real-time RT-PCR. Euro Surveill 25:25:pii=2000045. https://doi.org/10.2807/1560-7917. ES.2020.25.3.2000045

30. Dreier J, Störmer M, Kleesiek K (2005) Use of bacteriophage MS2 as an internal control in viral reverse transcription-PCR assays. J Clin Microbiol 43:4551-4557. https://doi.org/10.1128/JCM.43.9. 4551-4557.2005

31. Danion F, Ruch Y, Fourtage M, Kaeuffer C, Greigert V, Lefebvre N, Muller J, Nai T, Hansmann Y (2020) The good, the bad \& the hoax: when publication instantaneously impacts treatment strategies for COVID-19. Antimicrob Agents Chemother 64:e0112720. https://doi.org/10.1128/AAC.01127-20

32. Omidbakhsh N, Sattar SA (2006) Broad-spectrum microbicidal activity, toxicologic assessment, and materials compatibility of a new generation of accelerated hydrogen peroxide-based environmental surface disinfectant. Am J Infect Control 34:251-257. https://doi. org/10.1016/j.ajic.2005.06.002

33. Mawaddah A, Gendeh HS, Lum SG, Marina MB (2020) Upper respiratory tract sampling in COVID-19. Malays J Pathol 42:23-35

34. Yu C, Li L, Tuersun Y, Zhao X, Feng Q, Zhang T, Tay FR, Ma J (2020) Oropharyngeal secretion as alternative for SARS-CoV-2 detection. J Dent Res 99:1199-1205. https://doi.org/10.1177/ 0022034520940292

35. To KK-W, Tsang OT-Y, Chik-Yan Yip C et al (2020) Consistent detection of 2019 novel coronavirus in saliva. Clin Infect Dis 71: 841-843. https://doi.org/10.1093/cid/ciaa149

36. Wölfel R, Corman VM, Guggemos W, Seilmaier M, Zange S, Müller MA, Niemeyer D, Jones TC, Vollmar P, Rothe C, Hoelscher M, Bleicker T, Brünink S, Schneider J, Ehmann R, Zwirglmaier K, Drosten C, Wendtner C (2020) Virological assessment of hospitalized patients with COVID-2019. Nature 581:465469. https://doi.org/10.1038/s41586-020-2196-x

37. Liu Y, Liao W, Wan L, Xiang T, Zhang W (2020) Correlation between relative nasopharyngeal virus RNA load and lymphocyte count disease severity in patients with COVID-19. Viral Immunol. https://doi.org/10.1089/vim.2020.0062

38. Bidra AS, Pelletier JS, Westover JB, Frank S, Brown SM, Tessema B (2020) Comparison of in vitro inactivation of SARS CoV-2 with hydrogen peroxide and povidone-iodine oral antiseptic rinses. J Prosthodont. https://doi.org/10.1111/jopr.13220

Publisher's note Springer Nature remains neutral with regard to jurisdictional claims in published maps and institutional affiliations. 